\title{
Autoritarismo e homofobia: a repressão aos homossexuais nos regimes ditatoriais cubano $e$ brasileiro $(1960-1980)^{*}$
}

Douglas Pinheiro**

\begin{abstract}
Resumo
Partindo de dois filmes, o brasileiro Tatuagem e o cubano Fresa y chocolate, bem como dos contextos históricos a eles relacionados, este artigo busca investigar as violações perpetradas pelos regimes autoritários dos dois países contra homossexuais durante os anos de 1960-1980. Pretende-se, assim, dar visibilidade às memórias ocultadas pelo autoritarismo, a fim de contribuir para uma efetivação de políticas específicas de inclusão para os homossexuais brasileiros
\end{abstract}

Palavras-chave: Direito à memória, Ditadura militar, Homofobia.

" Recebido em 25 de julho de 2014, aceito em 30 de outubro de 2017.

** Professor da Faculdade de Direito e do Programa de Pós-Graduação em Direito da Universidade de Brasília (UnB), Brasilia, DF, Brasil. darpinheiro@gmail.com 
Authoritarianism and Homophobia: The Homosexual Repression in Cuban and Brazilian Dictatorial Political Systems (1960-1980)

\begin{abstract}
Based on two movies, the Brazilian film Tattoo and the Cuban film Strawberry and chocolate, as well as on the historical context related to them, this paper investigates the violations perpetrated by the authoritarian regimes of the two countries during the years 1960 to 1980. It proposes, then, to enlighten the memories hidden by authoritarism, in order to contribute to the implementation of specific inclusion politicies to Brazilian homosexuals.
\end{abstract}

Keywords: Memory Rights, Military Dictatorship, Homophobia. 


\section{Introdução}

1978. Periferia de Recife. Uma trupe de artistas libertários conhecida como Chão de Estrelas e liderada pelo homossexual Clécio Wanderley questiona o regime militar por meio de apresentações marcadas pelo erotismo e pelo deboche. Arlindo Araújo, vulgo Fininha, jovem do interior que à época presta serviço militar, ao levar uma encomenda para Paulo, transformista e irmão de sua namorada, acaba entrando em contato com esse universo intencionalmente transgressor. Do primeiro encontro, $e$ da imediata identificação entre Clécio e Fininha, surge uma relação homoafetiva que resgata de modo fílmico as políticas de censura e de controle social implementadas pela ditadura brasileira sobre os homossexuais.

O mote central de Tatuagem, filme dirigido por Hilton Lacerda e vencedor do Kikito 2013, prêmio máximo do Festival de Cinema de Gramado/RS, revela uma lacuna memorial no processo de esclarecimento das violações perpetradas pelo regime autoritário entre os anos de 1964-1985: a individualização das perseguições motivadas pela homofobia. É bem verdade que a Comissão Nacional da Verdade do Brasil dedicou um capítulo do segundo volume de seu relatório final a tais violações, elencando algumas das perseguições efetivadas pelo aparato repressor no serviço público, na mídia e nas ruas. Porém, ainda há muito a se memorializar, visto que a experiência ditatorial brasileira nas décadas de 1960 e 1970 não permitiu a formação de observatórios de direitos humanos que pudessem realizar registros exaustivos das agressões perpetradas pelo Estado contra homossexuais (Brasil, 2014).

Este artigo busca tematizar tal lacuna, fazendo-o numa perspectiva comparativa. Afinal, o domínio arbitrário efetivado pelos regimes ditatoriais não se restringe às estruturas estatais. As violações de direitos humanos por eles perpetradas não se voltam apenas contra os que questionam a legitimidade do governo despótico. No processo de controle e normalização social que acompanha um regime de exceção, os corpos de todos os 
cidadãos devem se adequar ao padrão de comportamento esperado pelo poder - uma pretensão que parece não depender do referencial político-ideológico que sustenta o regime. Afinal, embora os regimes ditatoriais existentes no Brasil e em Cuba entre os anos 1960-1980 apontassem para direções opostas na frisa ideológica, principalmente em relação ao pensamento comunista, ambos reprimiram as identidades de gênero $e$ as orientações sexuais tidas por desviantes, quer em nome de um padrão moral tradicional, quer em nome do perfil esperado para o homem novo revolucionário.

Ao apontar os processos de exclusão que operaram em regimes repressores de distintas matrizes ideológicas, pretende-se aqui iluminar a atual realidade político-constitucional brasileira. A polarização política por que passa o Brasil faz com que, por vezes, os atores sociais rotulem demandas específicas por inclusão como sendo reivindicações unicamente partidárias. Porém, em razão do princípio constitucional da dignidade da pessoa humana, deveriam elas constar em qualquer plataforma política. Diante disso, mais do que nunca é preciso resgatar uma perspectiva interseccional que torne visível e denuncie situações excludentes superpostas. Pessoas gays, lésbicas, transexuais, travestis, transgêneras, queers, intersexuais, assexuais ou de identidades $e$ sexualidades não normativas (LBTQIA+) acabam sendo estigmatizadas como o outro-pervertido a ser combatido - uma camada extra de exclusão para aquelas que, em muitos casos, já são privadas de direitos por questões econômico-sociais, étnicoraciais e/ou de gênero. Uma das formas de se resgatar a dignidades de tais pessoas, para além da polarização social, é tecer os fios narrativos da opressão que outros regimes repressores, de esquerda ou de direita, desferiram contra elas, apontando que a responsabilidade intergeracional pelas violações cometidas deve alcançar todo o espectro partidário.

Para tanto, valendo-se do cinema e de seu registro da realidade por meio do estranhamento, este texto se dividirá em dois momentos: no primeiro, ao indicar uma aproximação entre o filme brasileiro Tatuagem e o clássico cubano Fresa y chocolate, e 
cobrindo o intervalo temporal de 1960-1980, apontará o tratamento dispensado pelo regime de Fidel Castro às pessoas de identidades de gênero não normativas. Depois, abordará o tratamento dispensado pelo regime autoritário brasileiro a tal questão no mesmo período, enfatizando o caminho alternativo do desbunde trilhado pelos homossexuais. Por fim, espera-se resgatar os caminhos inclusivos apontados pela Comissão Nacional da Verdade do Brasil como forma de queering o constitucionalismo democrático do país.

\section{Cuba: entre maricones e homens novos}

Logo em seu primeiro encontro, Clécio instiga um desconcertado Fininha até levá-lo a seu quarto. Em tudo o diretor da trupe age como o amante experiente que seduz e inicia o jovem curioso. A sós, Clécio põe para tocar uma música de Dolores Duran e convence Fininha a dançar. Depois, já nus, acabam fazendo sexo, iniciando uma relação que levará o soldado a por fim em seu namoro heterossexual. Embora o diretor de Tatuagem não tenha assumido qualquer referência direta, é inevitável perceber como tais cenas dialogam com o clássico filme cubano de 1993, Fresa y chocolate.

No longa-metragem de Tomás Gutiérrez Alea, o homossexual de meia idade Diego, um produtor cultural, ao se aproximar do jovem militante comunista David em uma sorveteria, tenta seduzi-lo. Sem êxito, consegue, porém, convencêlo a ir até sua casa para pegar algumas fotos que alega ter tirado no passado, quando David protagonizou uma peça de teatro em sua escola. Ao receber o jovem em seu minúsculo apartamento, o experiente Diego põe uma música de Maria Callas e, após propositadamente derrubar café na camisa de David, convence-o a tirá-la sob o argumento de lavá-la rapidamente e, assim, evitar que se manche. $\mathrm{O}$ primeiro encontro, porém, termina com um enfurecido David deixando a casa de Diego, percebendo-se enganado ao não ver suas pretensas fotos. 
Embora o filme cubano não avance para uma relação homossexual, em ambas as narrativas estão presentes o agitador cultural libertário, o jovem vinculado a uma organização moralmente reacionária e o surgimento de um vínculo afetivo entre ambos, revelador das incoerências do regime político autoritário. Em uma entrevista, Senel Paz, autor do conto El lobo, el bosque y el hombre nuevo em que se baseou Fresa y chocolate, afirmou ter feito da personagem David um heterossexual convicto com a intenção de mostrar como qualquer pessoa, independentemente de sua orientação sexual, poderia compreender o homossexual e sua condição na sociedade cubana (Bejel, 1997).

A motivação revelada por Paz, ainda que verídica, parece não excluir a conveniência de se evitar um enfrentamento com o regime de Fidel Castro. Desde o Primeiro Congresso de Educação e Cultura de 1971, um equivalente da Revolução Cultural Maoísta, o Estado cubano passou por um processo de uniformização de todos os funcionários, educadores e artistas diretamente vinculados à educação das massas ou à representação cultural do país: a arte e, em especial, a literatura deveriam ser armas a serviço da Revolução. Não por acaso, no mesmo ano foi lançado pela Direção Política do Ministério do Interior (MININT) o concurso literário "Aniversário do Triunfo da Revolução", posteriormente incorporado ao calendário cultural cubano (Martínez, 2002a).

Tal premiação, reiteradamente destinada a romances policiais, acabou moldando a escrita nacional. A ênfase em tal gênero literário não era imotivada: por um lado, ele reforçava a imagem ideal da nova comunidade forjada pela prática revolucionária, em que o corpo policial, investido das virtudes necessárias, não apenas sustentava uma guerra permanente contra todos os inimigos do comunismo, como também apresentava um modelo de conduta a ser seguido. Por outro, ele cumpria um papel didático ao inventariar uma série de atividades e de comportamentos considerados delinquentes e traduzi-los de maneira clara ao leitor comum, capacitando-o à vigilância contínua dos demais membros de seu círculo social. Ambas as 
funções eram, em muitos casos, de conhecimento dos escritores. Luis Rogelio Nogueras, coautor do livro El cuarto círculo, vencedor do concurso de 1976, expressamente assumiu que sua obra policial pretendia ser um instrumento de educação social $e$ uma homenagem ao trabalho dos combatentes e oficiais do MININT (Martínez, 2002a).

Por esse motivo, o conto de Senel Paz marca uma dupla inflexão de forma e conteúdo. Em relação à forma, o texto se apresenta como uma narrativa policial fracassada (Martínez, 2002b). Após sair do apartamento de Diego, David procurou um companheiro de universidade mais afeito aos procedimentos do regime para denunciar o contrarrevolucionário homossexual que "recebia livros estrangeiros, falava mal da Revolução e era religioso" (Paz, 1991:30). Pouco impressionado com a denúncia, o colega de Juventude Comunista fez de David um agente e the confiou a investigação do suspeito $e$ a coleta de informações mais subsistentes. O jovem militante, porém, ao se reaproximar de Diego para comprovar seu comportamento subversivo acabou, aos poucos, tornando-se seu amigo, arruinando, assim, a investigação inicialmente planejada e ridicularizando o próprio gênero policial. Quanto ao conteúdo, o conto problematiza a definição de quem seja o homem novo.

A expressão, presente inclusive no título da narrativa de $\mathrm{Paz}$, remete a uma das teses veiculadas nos primeiros anos do governo castrista por Che Guevara. Em texto endereçado ao militante uruguaio Carlos Quijano, Che apresentava uma reação à crítica de que o socialismo anulava o indivíduo, invocando para tanto a existência de uma unidade dialética entre indivíduo e massa por meio da qual ambos interagiriam. Assim, a relação entre massa $e$ dirigentes não negaria o papel do indivíduo, mas reforçaria sua dupla existência: como ser único e como membro da comunidade - tese que justificaria a necessidade de superação da educação capitalista, marcada pelo isolamento. $\mathrm{O}$ homem, produto não acabado, deveria, pois, se sujeitar a um trabalho contínuo de formação para erradicar de sua consciência individual "as taras do passado" (Guevara, 2004:4). 
Essa erradicação das "taras do passado" seria alcançada por meio da educação direta, da educação indireta e da autoeducação. A educação direta seria realizada pelo Estado por meio de seu aparato burocrático criado em função da cultura geral, da técnica e da ideologia, com ênfase para a atuação do Ministério da Educação, e pelo aparato de divulgação do Partido Unido da Revolução Socialista Cubana - que, ainda naquele ano, se tornaria Partido Comunista de Cuba. A educação indireta seria a pressão realizada pelos que, diretamente educados, tivessem internalizado o novo conhecimento, direcionada aos que ainda não tivessem se sujeitado ao novo processo educacional; por fim, a autoeducação seria um processo consciente realizado por aqueles que, sofrendo a pressão da educação indireta, refletissem sobre sua conduta e se amoldassem à nova condição que acabariam reputando justa. Esse tríplice processo criaria, enfim, o homem novo comunista (Guevara, 2004).

Che tinha consciência de que esse processo não se faria sem intempéries. Porém, valendo-se da imagem da multidão que marcha para o futuro, o militante via nos líderes revolucionários a vanguarda responsável por abrir caminho e com o encargo de premiar os indivíduos que cumprissem com seus deveres e de "castigar aos que atentassem contra a sociedade em construção" (Guevara, 2004:5). Afinal, apenas as novas gerações já nasceriam livres do pecado original do capitalismo e poderiam "entoar o canto do novo homem com a autêntica voz do povo"; a geração que presenciara a queda do regime de Fulgêncio Batista não seria autenticamente revolucionária, devendo ser constantemente observada para que, em seus conflitos, não se pervertesse e nem as novas gerações (Guevara, 2004).

A menção de Che Guevara às "taras do passado" ganha um peso considerável quando posta em contexto. Naquele mesmo ano de 1965, foram criadas as Unidades Militares de Ajuda à Produção (UMAP) que, segundo a imprensa oficial, seriam locais destinados ao cumprimento de serviço militar obrigatório por todos os indivíduos desocupados que já não o estivessem prestando em Unidades Militares Regulares ou em Centros 
Militares de Ensino Tecnológico. Assim, tais unidades tanto atenderiam à demanda produtiva do Estado, arregimentando mão de obra forte para o corte da cana, quanto cumpririam uma função educativa de tais jovens, evitando que eles, segundo os defensores da medida, fossem no futuro "parasitas, incapazes de produzir algo, ou delinquentes contrarrevolucionários, ou delinquentes comuns, seres inúteis para a sociedade" (Baez, 1966:1).

Testemunhos de ex-internos e estudos posteriores, contudo, têm entendido que tais UMAPs voltadas ao plantio e ao corte de cana - todas situadas na província interiorana de Camagüey equivaleriam a verdadeiros campos de trabalho forçado. Para esses locais teriam sido destinados todos os grupos considerados antissociais, termo utilizado para nominar os indivíduos que promovessem crenças e práticas contrárias aos valores oficiais do regime, dentre os quais se incluíam religiosos (principalmente testemunhas de Jeová, adventistas, padres católicos e pastores protestantes), artistas, intelectuais e uma grande quantidade de homossexuais assumidos, não assumidos e presumidos (Guerra, 2010).

Embora as UMAPs tenham tido vida curta, sendo fechadas em 1967 (Martínez, 2002b), estima-se que, no geral, foram nelas internados de trinta a quarenta mil jovens, dos quais 72 morreram vítimas de abusos e torturas, 180 se suicidaram e 507 foram hospitalizados com traumas psiquiátricos (Fuentes, 1999). Embora nunca tenha mencionado tais números, é possível entrever o reconhecimento de violações pela própria imprensa oficial: "quando começaram a chegar os primeiros grupos que não eram nada bons, alguns oficiais não tiveram a paciência necessária $e$ perderam a cabeça ('perdieron los estribos')" (Baez, 1966:1) embora a mesma matéria ressalve que tais oficiais acabaram sujeitos a julgamento perante o Conselho de Guerra, sendo alguns expulsos das Forças Armadas.

Dos grupos encarcerados vinculados às "taras do passado", os únicos que mereceram campos específicos foram os homossexuais. José Mario, um homossexual enviado à UMAP 
2269, recorda que na entrada de seu campo havia uma placa com os dizeres "El trabajo los hará hombres", mote que parece adequar o lema de Auschwitz - "o trabalho vos libertará" - à tese do homem novo, mas que também significava, para os homossexuais, uma clara proposta de readequação de sua orientação sexual (Martínez, 2002b). Alguns ex-internos, como Jorge Ronet, Héctor Santiago e Heberto Padilla, chegam a mencionar a realização de experimentos pavlovianos em algumas unidades, por meio dos quais homossexuais recebiam choques elétricos ou de insulina quando expostos a fotos de homens nus $e$ comida quando expostos a filmes de sexo heterossexual (Tahbaz, 2013; Madero, 2016). Embora não se possa atestar se tais experimentos aconteciam em maior ou menor amplitude, em razão dos escassos testemunhos, eles acenam, ao menos, para uma inicial expectativa do regime quanto à viabilidade de uma "cura gay".

A homossexualidade, aos olhos do regime autoritário, era incompatível com a nova sociedade socialista. Sobre o tema, Fidel Castro expressamente afirmou em uma entrevista concedida em 1965 que "um desvio dessa natureza rompe com a ideia que temos sobre o que um militante comunista deve ser" (Ocasio, 2002:82). Porém, há divergências entre autores sobre a origem dessa contundente intolerância em Cuba, se anterior ou posterior ao castrismo. Para Arguelles e Rich (1984), considerando a forte herança patriarcal afroespanhola presente no meio rural, a solução para os homossexuais, antes da Revolução Cubana de 1959, era refugiar-se nas cidades, onde também viviam à margem ou abaixo da estrutura social. Numa época em que Cuba enfrentava altas taxas de desemprego e boa parte dos países desenvolvidos eram caracterizados por uma forte repressão sexual, a ilha capitalizava as experiências homoeróticas, quer para turistas estrangeiros, quer para nativos da pequena burguesia para quem a prática de sexo ocasional com outros homens não caracterizava homossexualidade.

Segundo as autoras, para além do comércio sexual, havia ainda um grande fluxo de mão de obra para as demais atividades 
ligadas ao crime organizado, como bebidas e jogos de azar, o que chegou a formar uma pequena burguesia homossexual que, paradoxalmente, procurava parceiros entre heterossexuais de baixa renda. Porém, apesar dessa perceptível presença, a homossexualidade não teria gerado uma "cultura gay", sendo tratada com violência ou reprovação nos ambientais familiares $e$ tradicionais, levando a crer que a tolerância então existente não decorria de uma aceitação social, mas sim dos ganhos econômicos por ela gerados (Arguelles, Rich, 1984). Reagindo a tal postura, especialmente quanto à negação de existência de uma "cultura gay" presente e difusa na sociedade cubana pré-revolucionária, Ana Maria Simó e Reinaldo Ramos (1984) apontaram uma série de artistas que, antes de Castro, expressaram vivências homossexuais, aberta ou discretamente, tais como a poesia de Emilio Ballagas e de Rolando Escardó, o teatro e os contos de Virgilio Piñera, a narrativa de José Lezama Lima e a pintura de Víctor Manuel.

Porém, independentemente dessa condição anterior, quer houvesse uma mescla social de visões de mundo, quer a cultura homossexual estivesse restrita ao campo das memórias subterrâneas, não há como identificar, em Cuba, a presença de sanção legal e de persecução oficial motivadas por orientação sexual antes de 1959. Com a Revolução Socialista, pelo contrário, ambas passaram a se manifestar. Já em 1961, ficou famosa a noite dos três "P", quando uma unidade especial da polícia secreta, $E l$ Escuadrón de la Escoria, deteve numa operação noturna várias prostitutas, proxenetas e pájaros [pássaros] - gíria cubana para homossexuais afeminados (Ocasio, 2002; Guerra, 2010).

Em 1973, após a criação e a extinção das UMAPs e a realização do Primeiro Congresso de Educação e Cultura, foi sancionada a Lei $\mathrm{n}^{\circ} 1249$, que tipificava os delitos contra os bons costumes e a ordem da família e punia a ostentação pública da homossexualidade. Em 1979, com o novo Código Penal Cubano, tal tipo penal foi revogado, dando lugar ao crime de escândalo público que punia com pena de três a nove meses aos que fizessem pública ostentação de sua condição homossexual, que 
praticassem atos homossexuais em lugar público ou mesmo em lugar privado caso pudessem ser involuntariamente vistos por outras pessoas, dentre outras condutas. Aliás, é justamente no ano de 1979 que se desenvolve a narrativa descrita no filme Fresa y chocolate. Diego, antes de fazer David entrar em seu apartamento, o alerta: havia sido detido em uma UMAP $e$ ainda era continuamente vigiado por seus vizinhos, personificando $\mathrm{O}$ histórico de violações perpetradas pelo regime (Paz, 1991).

Ao final do conto e do filme, Diego perde seu ofício de produtor cultural $e$, sem vislumbrar alternativas, decide sair do país. Durante as décadas de 1960 e 1970, a rota do exílio cubano preferencialmente destinou-se aos Estados Unidos. Entre 1952 e 1979, a Lei de Imigração estadunidense autorizava que o controle de fronteiras impedisse o ingresso no país a estrangeiros "sexualmente desviados"; porém, devido à Guerra Fria, tal legislação acabou não sendo utilizada em relação aos cubanos homossexuais, pois a acolhida de egressos esporádicos do regime castrista servia de bandeira anticomunista (Arguelles et al., 1984). O exílio de Diego não é retratado no filme. A narrativa, ao terminar antes de sua efetivação, deixa aberta a possibilidade de que sua saída possa ter acontecido somente no ano seguinte durante a emigração de Mariel.

Em 20 de abril de 1980, após o episódio em que um motorista jogou um ônibus de passageiros contra a embaixada do Peru para solicitar asilo, Fidel Castro anunciou que todos os cidadãos que desejassem deixar a ilha poderiam fazê-lo por meio do porto de Mariel, o que gerou um fluxo de mais de 120.000 cubanos em direção aos Estados Unidos. A permissão de deixar Cuba, porém, não era tão irrestrita quanto parece. Na verdade, a intenção de Castro era se ver livre da maior quantidade possível de indivíduos indesejados ao regime, o que obviamente incluía os homossexuais. Por isso, Antonio Conchez, considerado pelo Comitê de Defesa da Revolução um bom estudante e membro de uma familia decente, teve seu pedido de exílio inicialmente negado; apenas depois de comparecer perante as autoridades, intencionalmente com roupas vistosas, maquiagem no rosto $e$ 
postura afeminada, conseguiu a esperada autorização para deixar o país. O escritor Reinaldo Arenas testemunhou que não somente teve que se assumir homossexual perante as autoridades, como precisou caminhar diante de um grupo de psicólogas para que elas atestassem tal condição (Peña, 2007). Paradoxalmente, a mesma conduta ostensiva da orientação sexual que motivara a punição de homossexuais em Cuba tornou-se o requisito legitimador de sua saída do país.

Todos esses elementos da repressão homossexual cubana são discretamente apontados em Fresa y chocolate, filme que diante da amizade surgida entre David e Diego flerta com uma mensagem reconciliadora de possível superação da discriminação social no horizonte histórico. Dirigido por Tomás Alea como uma resposta ao filme-denúncia extremamente anticastrista Conducta impropria, de Néstor Almendros e Orlando Jiménez Leal, não é de se estranhar que tenha sido patrocinado pelo Instituto Cubano del Arte e Industria Cinematográficos, órgão que segundo seu criador, Alfredo Guevara (2010), teria sido "a primeira medida revolucionária tomada no campo da arte" com o fim de fazer do cinema "um instrumento de opinião e formação da consciência individual e coletiva".

Tal patrocínio parece explicar porque Diego menciona inúmeros autores estrangeiros homossexuais, como Federico García Lorca e Konstantínos Kaváfis, ao mesmo tempo em que oculta os literatos cubanos exilados Reinaldo Arenas e Virgílio Piñera; ou que, embora condene as UMAPs, faça questão de destacar a figura de Pablo Milanés, cantor que, mesmo detido em uma dessas unidades, sempre manteve sua crença no papel da Revolução; ou que reproduza o estereótipo do maricón afeminado, ainda que ele nunca faça sexo durante toda a narrativa; ou, por fim, que abra a possibilidade da personagem homossexual ser também caracterizada como um homem novo guevariano (Martínez, 2002b).

Quanto a isso, porém, é preciso lembrar a classificação social homoafetiva que Senel Paz pôs na boca de Diego, reproduzida igualmente no filme: no nível mais baixo da pirâmide 
estariam as locas, preocupadas apenas no prazer obtido com outros homens nos parques e nas saunas, provocadoras da sensibilidade popular não somente pelos seus trejeitos, mas também por sua futilidade, capazes de transformar em grandes desafios simples atos como pintar as unhas; os maricones, situados a meio caminho com características parciais dos dois extremos; e, na parte superior, os homossexuais, para quem o sexo ocuparia apenas um lugar na vida e nunca sobreposto ao dever social, caracterizados por serem trabalhadores, patriotas, firmes, sensíveis diante do fato social, o que inclusive os legitimaria a reivindicar a condição de aliados dos marxistas (Paz, 1991).

Diego define-se como um homossexual. Como tal seria digno de ser reconhecido como um revolucionário, como um homem novo. Porém, talvez por isso mesmo, seu exílio no final da narrativa acabe sendo coerente. Se na classificação de Senel, o homossexual é aquele que considera a supremacia do dever social, assim entendido como subserviência às vontades da massa e dos dirigentes, por mais intolerantes que fossem, só restaria a Diego uma saída: pegar um dos botes com destino aos Estados Unidos no porto de Mariel - como provavelmente fez.

\section{Brasil: dois lados, um preconceito}

Em 1967, Abelardo Barbosa, até então artista da TV Rio e já conhecido como Chacrinha, foi contratado pela TV Globo para apresentar dois programas: a "Discoteca do Chacrinha", às quartas-feiras, e a "Buzina do Chacrinha", aos domingos. Em 1969, o Velho Guerreiro já era líder nacional de audiência. Seu principal concorrente aos domingos era Flávio Cavalcanti, da TV Tupi, e a disputa pela liderança fazia com que os dois apresentadores recorressem a atrações popularescas. No início de 1972, José Bonifácio de Oliveira Sobrinho, o Boni, diretor de programação da TV Globo, decidiu melhorar o nível do programa de Chacrinha para qualificar a audiência $e$ valorizar financeiramente o horário, interferência que acabou gerando irritação no apresentador. 
A partir disso, como retaliação, Chacrinha começou a atrasar o final de seus programas, prejudicando a pontualidade da grade da emissora. No dia 3 de dezembro de 1972, após ver o apresentador extrapolar mais uma vez o horário de seu Buzina, Boni decidiu encerrar o programa por conta própria, o que levou Chacrinha a abandonar a TV Globo. Nos dias que se seguiram, a imprensa deu ampla cobertura ao caso. Em 7 de dezembro, após Chacrinha ter sido substituído por Agildo Ribeiro no programa que costumava apresentar às quartas, o Jornal do Brasil fez uma reportagem sobre o assunto ouvindo ambos os lados: Abelardo confirmou o pedido de rescisão e o justificou por ter a emissora mudado seu programa de horário cinco vezes; por outro lado, o porta-voz da TV Globo alegou que o problema com o apresentador não decorria do horário de sua atração, mas do fato de Chacrinha ter apresentado em seu programa "um afeminado", o que feria as regras morais, a ética e os bons costumes seguidos pela emissora.

Desde 1964, o Brasil estava sujeito a uma ditadura militar cuja política de controle e repressão alcançava também a esfera cultural. As redes de televisão, com capacidade abrangente de comunicação, recebiam uma atenção particular, devendo se adequarem ao padrão de moralidade igualmente repressor do governo. Nesse contexto, a objeção da TV Globo em exibir "um afeminado" em sua programação fazia eco à orientação governamental então vigente, conforme indicam alguns documentos dos acervos dos órgãos de informação e censura do regime militar, atualmente geridos pelo Arquivo Nacional.

Em 24 de abril de 1969, por exemplo, em ofício-resposta ao Juiz de Menores do Estado da Guanabara, atual cidade do Rio de Janeiro, o chefe do Serviço de Censura de Diversões Públicas esclarecia já ter tomado as medidas cabíveis para retirar "dos programas de TV da Guanabara, os quadros" que explorassem "a figura do homossexual" (Brasil, 1969b). Em 1972, porém, parece que a briga por audiência havia momentaneamente relativizado tal orientação, segundo pode se concluir de um ofício encaminhado pela agência de Salvador/BA à agência central do 
Serviço Nacional de Informação (SNI). Tal documento, cuja ementa do assunto era "promoção de homossexualismo na imprensa e TV", tratava de uma série de reportagens que havia circulado na imprensa soteropolitana relativas ao Congresso de Homossexuais de Caruaru/PE, à escolha do estilista Dener para paraninfo de um curso de Jornalismo, de Pernambuco, e à presença de homossexuais em programas de televisão.

Sobre este último assunto, o informante dizia estranhar a liberalidade com que a Censura Federal estava tratando a programação televisiva do domingo, já que as alternativas existentes no horário nobre eram comprometidas por uma "estranha fauna (...), Clóvis Bornay, no 'Programa Silvio Santos', Dener, no 'Programa Flávio Cavalcanti', ou o costureiro Clodovil, na 'Buzina do Chacrinha'" (Brasil, 1972a). Tais jurados dos programas de auditório, de "masculinidade dúbia (...) confirmada pelos trejeitos femininos, expressões faciais duvidosas, a voz em falsete", não possuiriam "os mínimos requisitos morais para servirem de 'modelos', 'arquétipos' ou ídolos da mocidade do Brasil" - um papel que acabariam desempenhando pelo fato de serem apresentados em tais programas como sumidades, o que criaria sobre eles "uma imagem socialmente aceita e responsável" (Brasil, 1972a). O documento, ao final, recomendava maior rigor da Censura Federal, sugerindo fosse proibida a veiculação de notícias sobre homossexuais.

As reportagens de Salvador não incomodaram apenas a agência local do SNI, mas também o Centro de Informações de Segurança da Aeronáutica (CISA) que, cinco dias depois, igualmente encaminhou um ofício à agência central do SNI. O documento alegava que os Oficiais do CISA eram frequentemente abordados por pessoas de seu convívio social questionando se os órgãos competentes estavam tomando medidas convenientes contra a exibição pública de homossexuais, "pois seus filhos, ainda em idade tenra, inocentemente adora[va]m imitar a voz e feitos do Sr. Dener e outros" (Brasil, 1972b). Posteriormente, o CISA novamente questionou os pretensos ataques à moral das famílias, quando, em 11/11/1972, o cantor Caetano Veloso se 
apresentou no Teatro Castro Alves de Salvador/BA "como um homossexual, pintado de batom e com trejeitos afeminados" (Brasil, 1972c).

Tais documentos indicam um claro mal-estar nos órgãos de controle do regime militar quanto à exibição de homossexuais na esfera pública - nada, porém, que comprovasse alguma medida concreta do governo em relação à TV Globo, o que ratificaria o argumento de dispensa de Chacrinha. Porém, um ofício expedido pela Superintendência Regional de São Paulo da Secretaria de Censura de Diversões Públicas em 24/12/1976 e endereçado à sede em Brasilia/DF, motivado pelo programa "Buzina do Chacrinha" exibido pela TV Tupi em 18/12/1976, parece indicar que houve alguma gestão da ditadura em relação às emissoras de televisão nos anos anteriores.

Tal ofício denunciava que o apresentador Abelardo Barbosa havia apresentado em seu programa, na condição de jurado, o cabeleireiro Silvinho. Ao analisar o vídeo do programa, a sede da censura federal, por meio de parecer, considerou serem "os gestos feminis do referido cabelereiro passíveis de influenciar o menor despreparado" em decorrência de seu sucesso e popularidade. Por fim, para justificar a advertência a Chacrinha, lembrava que "a presença insinuante e feminina do personagem, incid[ia] em afrontosa semelhança com as dos costureiros Dener e Clodovil, afastados em outras épocas de iguais programas" (Brasil, 1977).

O caso Chacrinha revela, pois, uma postura recorrente do regime militar em relação aos homossexuais. Havia até uma certa tolerância em relação às suas práticas "contanto que permanecessem em espaços fechados, deixando seu ambiente semiclandestino apenas uma vez por ano, durante as festividades de carnaval" (Green, 2000:399). Assim como o regime autoritário cubano tinha aversão à ostentação social da homossexualidade, a ditadura militar brasileira não poupava esforços para excluir os afeminados da esfera pública e, principalmente, dos meios de comunicação em massa. Nesse contexto é que se deu a vedação à presença de jurados homossexuais nos programas de auditório das emissoras de televisão, imposição admitida e utilizada pelas 
emissoras como moeda de barganha para reivindicar facilidades na importação de equipamentos (Rodrigues, 2014). Graças a tal processo de invisibilização é que o Congresso de Homossexuais de Caruaru/PE, organizado por um padre da Igreja Ortodoxa Italiana e agendado para junho de 1972, não obteve a prévia autorização da autoridade policial local e acabou sendo cancelado (Rodrigues, 2012). Por isso, ainda, em 1973, o Departamento de Turismo do Rio de Janeiro, que patrocinava o baile de gala do Teatro Municipal, famoso por seu exuberante concurso de fantasias, cancelou a competição masculina, para evitar dar ênfase à participação destacada dos homossexuais (Green, 2000).

A postura repressiva da ditadura militar em relação aos homossexuais não pode, porém, ser dissociada da fundamentação ideológica de seu autoritarismo. Cunhada pelos teóricos da Escola Superior de Guerra (ESG) - um instituto de altos estudos militares, criado em 1949 nos moldes da National War College estadunidense $e$ fortemente influenciado pela postura anticomunista do pós-Segunda Guerra Mundial -, a Doutrina de Segurança Nacional repensava o conceito de defesa pátria, dando menor destaque à proteção das fronteiras e do território geográfico e enfatizando a luta contra o inimigo interno do próprio Estado. Com isso, a guerra clássica, combate declarado entre nações $e$ grupo de nações, dava lugar à guerra revolucionária, "agressão indireta" cuja "essência [era] a conquista do poder em uma nação para o Comunismo Internacional, utilizando a própria população da nação-alvo como instrumento de luta" (Brasil, 1969a:10).

Segundo os documentos secretos de estudo militar, para conseguir seu objetivo a guerra revolucionária pretensamente adotaria duas estratégias simultâneas: "a dissolução física e moral do corpo social" e "a construção (...) da sociedade revolucionária totalitária no próprio seio da sociedade vigente e às suas custas" (Brasil, 1959:17). Curiosamente, a percepção imagética de tal dissolução social foi sendo cada vez mais sexualizada, $e$ a juventude, força motriz nacional, sendo percebida como alvo preferencial dos processos de degeneração física e moral decorrentes da subversão, um giro argumentativo bastante 
perceptível na produção bibliográfica das décadas de 1960 e 1970 vinculada à Escola Superior de Guerra (Cowan, 2007).

Para além das expressões "sedução comunista" $e$ "aliciamento dos jovens", recorrentes em vários documentos, é possível destacar alguns textos e conferências em particular. Em 1973, por exemplo, no âmbito dos estudos militares sobre a problemática da juventude, o psiquiatra José Lemes Lopes, ao proferir uma palestra na ESG, alegou ser hormonal a tendência dos jovens em aderir a práticas subversivas. Confusos com a maturação de sua função reprodutiva, eles seriam acometidos por uma irracionalidade patológica que os faria vulneráveis às ideologias de esquerda - algo apenas superado quando funcionalmente desempenhassem "o papel de adultos heterossexuais" (Cowan, 2007:467). No ano seguinte, também por meio de uma conferência proferida na ESG, a psicóloga Noemi da Silveira Rudolfer, além de reforçar a ideia de que os impulsos sexuais predisporiam os adolescentes à perturbação social de matriz esquerdista, também apontou que tal radicalismo juvenil decorria de condições hereditárias degenerativas, tais como "a insuficiência somática", "o baixo tônus muscular" e "a orientação homossexual" (Cowan, 2007).

Em 1974, Guilardo Martins Alves, médico que havia sido reitor biônico na Universidade Federal da Paraíba, produziu um documento de estudo em que afirmava que a rebeldia dos jovens ameaçava os imperativos da "Revolução de 1964" por meio dos abusos e da acentuada permissividade em relação ao sexo. Um relatório de grupo de 1975 explicava melhor tal risco: o comportamento sexual contemporâneo, ao supostamente promover doenças, marcaria de modo permanente o físico e o psicológico da juventude nacional, comprometendo, assim, o desenvolvimento e a segurança do Brasil, impedindo-lhe a marcha rumo a seu "grande destino". A superação de tal ameaça passaria por uma reforma da então "defeituosa educação sexual", excluindo "doenças" como "a sexualidade do consumo", "a iniciação prematura de crianças nos mistérios do sexo", "a 
promiscuidade", "a permissividade" $e$ "o amor livre $e$ irresponsável" (Cowan, 2007).

Desse modo, segundo a perspectiva da Doutrina de Segurança Nacional, a presença da homossexualidade na esfera pública e nos meios de comunicação não seria apenas uma ofensa aos valores tradicionais das famílias, mas também parte do processo de desintegração social que, se não provocado por forças comunistas, bem atendia a seus interesses, razão por que a repressão aos homossexuais se inseria numa lógica ampliada do combate à guerra revolucionária levada a cabo pela ditadura militar. Pode parecer, então, à primeira vista, que a militância de esquerda acolhesse os homossexuais e suas demandas no esforço de somar forças contra o regime. Porém, a esquerda acabou não oportunizando o empoderamento das identidades de gênero não normativas.

É possível que tal postura tenha ecoado, de algum modo, o modelo do regime castrista cubano por, pelo menos, três motivos: (i) vários militantes brasileiros receberam treinamento em Cuba, tendo, pois, contato com um discurso ainda mais repressor sobre os homossexuais; (ii) a teoria do homem novo guevariano, que sacrificava os prazeres imediatos do corpo em nome da revolução, já se disseminara pela América Latina; (iii) a figura mítica do próprio Che Guevara, morto em 1967, havia consolidado a imagem do homem revolucionário como sendo barbudo, viril, não afeminado (Green, 2012). Porém, mesmo a esquerda que não se espelhava no modelo cubano reprovava a homossexualidade. $\mathrm{O}$ Partido Comunista Brasileiro $e$ as suas várias ramificações dos anos 1960 partilhavam, na sua quase totalidade, uma compreensão comum ao movimento comunista internacional, tanto stalinista quanto maoísta, de que as práticas homossexuais eram um produto da decadência burguesa que desapareceria com a derrota capitalista e a consequente vitória socialista (Green, 2007).

$\mathrm{Na}$ medida em que a homossexualidade despertava desconfiança na esquerda comunista, muitos militantes homossexuais evitaram se assumir publicamente. Diante de um 
caso recuperado por testemunhos, ocorrido na prisão paulista de Tiradentes, tal postura parece bastante justificável. Em 1972, dois presos políticos que partilhavam a mesma cela em tal presídio passaram a ter uma relação homoafetiva, assumindo-a publicamente. Embora, a princípio, os demais presos, pertencentes a distintas organizações revolucionárias, tivessem decidido se afastar do casal, posteriormente passaram a cogitar a possibilidade de um justiçamento, ou seja, de uma execução sumária, prática aplicável na época aos militantes acusados de traição, do que se conclui que a homossexualidade, para o grupo, era uma postura contrarrevolucionária. Ciente de tal ameaça, um dos ameaçados resolveu desafiar seus potenciais algozes: afinal, vários dentre eles já haviam delatado colegas após torturas, algo que ele, apesar de homossexual e pretensamente frágil, não havia feito. Somente diante de tal confrontação é que a proposta de execução do casal se dissipou (Green, 2012).

É óbvio que ocorreram práticas homoinclusivas pontuais na esquerda durante o intervalo temporal abordado por este texto. $\mathrm{O}$ próprio James Green (2014) relata sua experiência na Facção Homossexual da Convergência Socialista, organização trotskista fundada em 1978 por militantes do clandestino Partido Socialista dos Trabalhadores. Porém, tal facção, que chegou a arregimentar vinte e cinco militantes, acaba sendo um exemplo de exceção que confirma a regra. Talvez, por isso, a forma como os homossexuais brasileiros melhor afirmaram sua identidade durante a maior parte do regime de repressão parece ter sido a terceira via complexa $e$ multifacetada do desbunde. O termo, na época, servia para designar tanto os jovens ligados à contracultura, que viviam em comunidades alternativas e faziam uso de alucinógenos, quanto os militantes de esquerda que abandonavam a luta contra o regime militar (Green, 2012; Dunn, 2014). Segundo João Silvério Trevisan (2011:284), desbundar significava abandonar

os compromissos com a direita e a esquerda militarizadas da época, para mergulhar numa liberação individual, 
baseada na solidariedade não-partidária e muitas vezes associada ao consumo de drogas ou à homossexualidade.

Dentre os expoentes artísticos do desbunde homossexual, destacaram-se o cantor Ney Matogrosso, egresso da banda Secos \& Molhados, e o grupo teatral carioca Dzi Croquetes (Trevisan, 2011). Porém, foi uma companhia de menor expressão nacional, radicada em Pernambuco, que inspirou Hilton Lacerda na caracterização da trupe Chão de Estrelas do filme Tatuagem: o Vivencial Diversiones. Surgido como um grupo de jovens ligado à Igreja Católica por meio da Associação de Rapazes e Moças do Amparo (ARMA), encarregado inicialmente de dramatizar o evangelho e de animar as missas da paróquia do Amparo, bairro de Olinda/PE, o Vivencial tornou-se um coletivo teatral independente quando, ao comemorar os dez anos da ARMA, em 1974, seus membros decidiram apresentar no Mosteiro de São Bento um espetáculo transgressor sobre a temática das drogas, da homossexualidade e da política, o que acabou causando o rompimento com a igreja.

Com figurinos de retalhos, cópias de roteiro do espetáculo transcritas a próprio punho e canhões de iluminação feitos de latas recicladas, apresentando-se em distintos lugares até conseguirem adquirir um terreno no meio do mangue, numa região periférica entre Recife e Olinda, o Vivencial Diversiones conquistou um público cada vez maior em seus distintos espetáculos. No dizer de Fábio Costa, um de seus ex-integrantes, o grupo "experimentou os prazeres do corpo, misturou estéticas, reuniu bichas doutores e bichas analfabetas", "falou e disse que o discurso político não precisa[va] ser chato, pod[ia] ter doses generosas de humor" (Diniz et al., 2011).

Ao reportar a dinâmica das apresentações para o jornal gay Lampião da Esquina, em 1979, Trevisan fez um claro retrato do desbunde característico do grupo. Em um barracão improvisado, com panos coloridos, chão de cimento rústico e lustres esféricos, aproximadamente duzentas pessoas, dentre as quais a grande maioria heterossexuais, se espremiam para ver um variado 
espetáculo "quase ininterrupto das 9 da noite às 2:30 da madrugada: uma peça, danças, dublagens, um palhaço pornógrafo, grupos de música, strip-teases e números humorísticos" (Trevisan, 1979:15). A crítica à moral tradicional era feita de vários modos: pelo tipo religioso que aparecia com mitra e paramentos mas que, ao se virar, mostrava as nádegas nuas; pelo striptease duplo feito de costas que, ao final, surpreendia a plateia ao revelar que uma das duas figuras femininas era uma travesti; pelo ator peludo trajando vestido e meia calça arrastão que recitava ou um inesperado discurso sexo-político ("Eu sou da Óposição, mas da Ó-posição incômoda, porque a oposição neste país já faz parte da situação") ou um monólogo de afirmação da identidade transgressora ("Sou aceito pelo folclore que faço e porque traduzo em atos o desbunde que está enrustido nas pessoas") (Trevisan, 1979).

A atuação do grupo era acompanhada de perto pelo regime militar. No dia da reportagem de Trevisan, três policiais estavam presentes no camarim. Fábio Costa testemunhou que a companhia reiteradamente se recusava a submeter seus espetáculos à censura prévia, tentando burlar a proibição - o que não evitava que fossem muitas vezes ameaçados com "metralhadora no ouvido" (Diniz et al., 2011). No filme, porém, Lacerda buscou retratar o confronto entre esses dois mundos por meio de uma intencional lacuna: enquanto a trupe Chão de Estrelas apresentava um dos espetáculos dirigidos por Clécio, com a participação nua de seu amante Fininha, um batalhão da polícia se deslocava em direção ao teatro para reprimir os artistas; porém, no exato momento da invasão policial, a sequência é cortada. Lacerda (2014), em entrevista, afirmou que não tinha como retratar tal enfrentamento ficcional de modo tão verossímil como eram os realmente ocorridos.

Ao não apresentar a detenção dos artistas, Tatuagem acaba problematizando um outro aspecto da repressão homossexual nos anos de chumbo: o das prisões arbitrárias. Com algum esforço, as travestis do Vivencial Diversiones, reconhecidas como artistas e identificadas como "transformistas", haviam obtido junto à polícia 
um salvo conduto (Guimarães et al., 1979), o que as resguardou de serem presas sob acusação de vadiagem, recurso utilizado pela repressão militar para evitar a prostituição ou mesmo a exibição pública de travestis. $\mathrm{O}$ procedimento, bastante utilizado nas grandes capitais, consistia em exigir a comprovação de emprego remunerado; em não havendo, concedia-se trinta dias à travesti para que conseguisse assinar sua carteira de trabalho. Do contrário, caso fosse novamente detida sem atender a este requisito, ficava sujeita a até três meses de prisão. Porém, mesmo as que obtinham um emprego formal poderiam ser presas sob acusação de perturbação da ordem pública - o que só indica como foi excepcional a garantia obtida pelas artistas pernambucanas (Green, 2000).

Por fim, se em Fresa y chocolate o agitador cultural acaba se tornando migrante, no filme de Hilton Lacerda é Fininha quem deixa a terra natal. Expulso da corporação, o ex-soldado tenta reconstruir a vida em São Paulo. Numa carta escrita a Tuquinha, filho que Clécio tivera em um antigo relacionamento heterossexual, ele narra as dificuldades de conseguir emprego na metrópole, principalmente em razão da letra "c" tatuada no peito, uma lembrança visível do seu romance homoafetivo. E, embora o filme não avance até 1980, é possível projetar Fininha testemunhando a Operação Limpeza encabeçada pelo delegado José Wilson Richetti, uma ação policial que, com truculência, pretendeu acabar com a presença homossexual nas ruas do centro da capital paulista (Trevisan, 1980). Assim, Fininha poderia perceber que, no processo de afirmação da própria identidade, cada um traz suas próprias cicatrizes - embora, durante o regime militar, a quase totalidade dessas marcas para os homossexuais tenha sido fruto da repressão intolerante.

\section{Considerações finais}

Por meio dos filmes Tatuagem e Fresa y chocolate e da memória histórica de opressão que eles permitem reativar, é possível perceber como projetos autoritários quer de esquerda 
quer de direita negaram aos homossexuais o direito a ter direitos. Especificamente nos casos cubano e brasileiro, fica evidente a preocupação de revolucionários e militares em ocultar a presença de afeminados do espaço público, obrigando-os a assumir uma postura corporal padronizada e a transmitir seu capital simbólico apenas por meio de memórias subterrâneas ao discurso oficial de bons costumes ou de militância ideal. Por isso, uma justiça transicional que busque uma transição efetiva para a democracia precisa resgatar as experiências suprimidas pelo ritmo oficial de uma política tradicional produtiva e reprodutiva, permitindo que elas se expressem em sua própria pluralidade.

No Brasil, o segundo volume do relatório final da Comissão Nacional da Verdade abordou, mesmo que de modo resumido, algumas das repressões perpetradas contra homossexuais durante o regime militar. Ao final do texto, há uma série de recomendações que apontam para uma prática social futura que respeite a diversidade: criminalização da homolesbotransfobia, garantia legal da livre identidade de gênero, reconhecimento estatal das violações de direitos com consequente pedido público de desculpas, identificação e preservação dos lugares de memória relativos às narrativas de resistências de pessoas LGBTQIA+, bem como concessões de reparações e indenizações para aquelas que tenham sofrido os efeitos da repressão (Brasil, 2014). Sem dúvida, a visibilização das violências de cunho homofóbico foi um passo importante que nem sempre tem sido acolhido em outros processos transicionais.

Porém, a superação do padrão normativo viriarcal $e$ heteronormativo que ainda molda a democracia brasileira requer um choque imediato de inclusão em várias frentes. Politicamente, os grupos de esquerda e de direita precisam ser lembrados pela sociedade civil organizada da responsabilidade intergeracional que têm na acumulação do capital discriminatório nacional em relação aos homossexuais. Administrativamente, o Estado deve ser cobrado por meio de medidas próprias de accountability, mesmo que nas instâncias internacionais de direitos humanos, quanto às mortes com motivação homofóbica que acontecem por ação ou 
omissão dos governantes e de seus aparatos de segurança pública. Juridicamente, os aplicadores do direito precisam reconhecer que os cidadãos, na vivência de suas subjetividades, dão conteúdo às garantias constitucionais, munindo, pois, de força normativa os diversos desenhos afetivos que não necessariamente são equiparados à união matrimonial de um casal. Mais que isso, o direito precisa ser questionado quanto à sua capacidade de regular a vontade dos sujeitos em relação a seus próprios corpos $e$ desejos, permitindo, pois, que se abram espaços e temporalidades de efetiva liberdade.

Espera-se, acima de tudo, que o processo crescente de afirmação da diversidade consiga criar uma ética da alteridade no país, capaz de impactar cada recanto nacional por meio do reconhecimento de gêneros, subjetividades e sexualidades não normativas. As diásporas, que bem podem expressar a busca de novas experiências, quando relacionadas aos homossexuais normalmente correspondem a planos de fuga ou estratégias de sobrevivência. No fim dos filmes abordados, por exemplo, há trânsitos dessa natureza. Fininha, expulso da corporação, migra de Recife para São Paulo. Diego, sem espaço em sua própria terra natal, migra de Cuba para os Estados Unidos. A hospitalidade inclusiva, um traço humanitário de algumas localidades, não pode servir de pretexto para que outras cidades, regiões ou Estados soberanos se sintam confortáveis em sua prática discriminatória expulsiva, mesmo que velada. Um regime autoritário normalizador, afinal, retira de muitos o direito de trilhar seu próprio caminho. A democracia plural não pode existir sem resguardar, em todos os seus espaços, a pluralidade de percursos.

\section{Referências bibliográficas}

AGILDO anima "Discoteca" e confirma rompimento do Chacrinha com TV Globo. Jornal do Brasil. Rio de Janeiro, 7/12/1972 [http://www.tvpesquisa.com.puc-rio.br/ImprimDoc.asp?CodRegistro $=384$ - acesso em: 10 jul. 2014].

AlEA, Tomás Gutiérrez. Fresa y chocolate. La Habana, ICAIC, 1993. 
ARGUELLES, Lourdes; RiCH, B. Ruby. Homosexuality, homophobia, and revolution: notes toward an understanding of de Cuban lesbian and gay male experience, part I. Signs: Journal of Women in Culture and Society 9(4), Chicago, summer/1984, pp.683-699.

BAEZ, Luis. Unidades Militares de Ayuda a la Producción (UMAP). Granma, La Habana, 14 abr. 1966.

BEJEL, Emilio. "Strawberry and Chocolate" coming out of de Cuban closet. South Atlantic Quarterly 96(1), Durham, 1997, pp.65-82.

CowAN, Benjamin A. Sex and the security State: gender, sexuality, and "subversion" at Brazil's Escola Superior de Guerra, 1964-1985. Journal of the History of Sexuality 16(3), Austin, jul/2007, pp.459481.

DINIZ, Pollyanna; MouRA, Ivana. Grupo de teatro Vivencial é relembrado com homenagens no palco e no cinema. Diário de Pernambuco, Recife, 20 nov. 2011 [http://www.old.diariodepernambuco.com.br/ economia/nota.asp?materia $=20111120133752$ - acesso em: 3 jul. 2014].

DunN, Christopher. Desbunde and its discontents: counterculture and authoritarian modernization in Brazil, 1968-1974. The Americas 70(3), New Orleans, jan/2014, pp.429-458.

FuENTES, Norberto. Dulces guerreiros cubanos. Barcelona, Seix Barral, 1999.

GREEN, James Naylor. Além do carnaval: a homossexualidade masculina no Brasil do século XX. São Paulo, Unesp, 2000 [1999].

. (Homo)sexuality, human rights, and revolution in Latin America. In: WASSERSTROM, Jeffrey; HUNT, Lynn; YounG, Marilyn; GRANDIN, Gregory (ed.). Human rights and revolutions. Lanham, Rowman and Littlefield, 2007, pp.139-154.

"Who is the macho who wants to kill me?" Male homosexuality, revolutionary masculinity, and the Brazilian armed struggle of the 1960s and 1970s. Hispanic American Historical Review (92:3), Durham, 2012, pp.437-469.

- O grupo Somos, a esquerda e a resistência à ditadura. In: GREEN, James; QUINALHA, Renan (org.). Ditadura $e$ 
homossexualidades: repressão, resistência e busca da verdade. São Paulo, EdUFSCar, 2014, pp.177-200.

GUERRA, Lillian. Gender policing, homosexuality and the new patriarchy of de Cuban Revolution, 1965-70. Social History (35:3). London, ago/2010, pp.268-289.

GuEvarA, Alfredo. Realidades y perspectivas de un nuevo cine (republicação). Cine Cubano on line (18-19). La Habana, jul$\mathrm{dez} / 2010$

[www.cubacine.cult.cu/sitios/revistacinecubano/digital1819/index.htm. - acesso em: 11 jul. 2014].

GuevarA, Ernesto (Che). El socialismo y el hombre nuevo en Cuba. In: Guevara, Ernesto (Che). Pensamiento y acción: selección de escritos y discursos. Buenos Aires, Nuestra Propuesta, 2004 [1965], pp.3-7.

GuimarãES, Ana Maria; LACERDA, Ângela. Rebolado "gay" sacode as noites do Recife. Diário de Pernambuco. Recife, 24/06/1979, pp.A12.

LACERDA, Hilton. Tatuagem. Recife, Rec Produtores Associados, 2013.

Entrevista [http://cinefestivais.com.br/entrevista-com-hiltonlacerda-diretor-de-tatuagem - acesso em: 4 jul. 2014].

MADERO, Abel Sierra. "El trabajo os hará hombres": Masculinización nacional, trabajo forzado y control social en Cuba durante los años sessenta. Cuban Studies (44), Pittsburgh, 2016, pp.309-349.

MARTínEZ, Santiago Esteso. Los excluidos de la masculinidade: espacio nacional y regulaciones sexuales en Cuba. Dossiers feministes (6), Castelló de la Plana, 2002a, pp.73-96.

. Las estrellas más brillantes. Maricones y hombres nuevos en el cine de la Revolución: Cuba 1961-1993. Orientaciones: Revista de Homosexualidades (3), Madrid, jan-jun/2002b, pp.103-124.

OCASIO, Rafael. Gays and the Cuban Revolution: the case of Reinaldo Arenas. Latin American Perspectives (29:2), Riverside, mar/2002, pp.78-98.

PAZ, Senel. El lobo, el bosque y el hombre nuevo. Ciudad de México, Era, 1991. 
PEÑA, Susana. "Obvious gays" and the State gaze: Cuban gay visibility and U.S. immigration policy during the 1980 Mariel Boatlift. Journal of the History of Sexuality (16:3), Austin, sept/2007, pp.482-514.

Rodrigues, Rita de Cássia Colaço. De Daniele a Chrysóstomo: quando travestis, bonecas e homossexuais entram em cena. Tese (Doutorado em História Social), Instituto de Ciências Humanas e Filosofia da Universidade Federal Fluminense, Niterói-RJ, 2012.

- De Denner a Chrysóstomo, a repressão invisibilizada: as homossexualidades na ditadura. In: GREEN, James; QUINALHA, Renan (org.). Ditadura e homossexualidades: repressão, resistência e busca da verdade. São Paulo, EdUFSCar, 2014, pp.201-244.

Simó, Ana María; RAmOS, Reinaldo García. Hablemos claro. Mariel: Revista de Literatura y Arte (5), New York, primavera/1984, pp.9-10.

TAHBAZ, Joseph. Demystifying las UMAP: the politics of sugar, gender, and religion in 1960s Cuba. Delaware Review of Latin American Studies (14:2), Newark, 2013 [http://www.udel.edu/LAS/Vol142Tahbaz.html - acesso em: 04 jul. 2014].

TREVISAN, João Silvério. Vivencial Diversiones apresenta: frangos falando para o mundo. Lampião da Esquina (18), Rio de Janeiro, nov/1979, pp.15.

. São Paulo: a guerra santa do Dr. Richetti. Lampião da Esquina (26). Rio de Janeiro, jul/1980, pp.18.

. Devassos no paraíso: a homossexualidade no Brasil, da colônia à atualidade. Rio de Janeiro, Record, 2011 [1986].

\section{Fontes}

BRASIL. Escola Superior de Guerra. Departamento de Estudos. Introdução ao estudo da guerra revolucionária, por Cel. Augusto Fragoso (Reservado, C-85-59). Rio de Janeiro, 1959.

. Escola Superior de Guerra. Departamento de Estudos. Aspectos da guerra contemporânea: a guerra revolucionária (Reservado, C-2069). Rio de Janeiro, 1969a. 
- Arquivo Nacional (Brasília). Fundo Divisão de Censura de Diversões Públicas. Ofício n ${ }^{\circ}$ 230/69-SCDP do Serviço de Censura de Diversões Públicas. Sem local, 24/04/1969b.

- Arquivo Nacional (Brasília). Fundo Serviço Nacional de Informações. Informação no 1321/SNI/ASV/1972 do Serviço Nacional de Informação, Agência de Salvador. Salvador, 13/04/1972a.

- Arquivo Nacional (Brasília). Fundo Centro de Informações de Segurança da Aeronáutica. Encaminhamento no 105/CISA-ESC-RCD do CISA - Ministério da Aeronáutica. Salvador, 18/04/1972b.

- Arquivo Nacional (Brasília). Fundo Centro de Informações de Segurança da Aeronáutica. Encaminhamento n 329/CISA-ESC-RCD do CISA - Ministério da Aeronáutica. Salvador, 23/11/1972c.

- Arquivo Nacional (Brasília). Fundo Divisão de Censura de Diversões Públicas. Ofício no 10.804/76-SCDP/SR/SP do Serviço de Censura de Diversões Públicas, Superintendência Regional de São Paulo. São Paulo, 24/12/1976.

- Arquivo Nacional (Brasilia). Fundo Divisão de Censura de Diversões Públicas. Parecer $n^{\circ}$ 16/77-DCDP sobre o programa "Buzina do Chacrinha" n² 20. Brasília, 03/01/1977.

. Comissão Nacional da Verdade. Relatório: textos temáticos, vol. 2. Brasília, CNV, 2014. 